RIXROAU, (. N. Reaction time and conditioning: lixtinction, recovery, and disinhibition. Joumal of F xperimental Psy chology, 1937, 20 , 468.476.

SINGH, D, \& WICKENS, D, D. Disinhibition in instrumental conditioning. Journal of Comparative \& Phy siological Psy chology, 1968, 66, 557-559.

SKINNER, B, I. A failure to obtain "disinhibition." Journal of General Psy chology, 1936, 14, 127-135.
YAMAGUCHI, H. G., \& LADIORAY, G. Disinhibition as a function of extinction trials and stimulus in tensity. Journal of ('omparative \& Physiological Psy chology, 1962, 55, 572-577.

\section{NOTI}

1. This investigation was supported by Grant GB7674 from the National Science Foundation. Reprints may be obtained from D.P. Ferraro, Department of Psychology, University of New Mexico, Albuquerque, New Mexico 87106.

\title{
Learned resistance to punishment and subsequent responsiveness to the same and novel punishments
}

WILLIAM TERRIS, DePaul University, Chicago, Ill. 60614 and MICHAEL BARNES, ${ }^{2}$ University of Oklahoma, Norman, Okla. 73069

In a factorial study, rats were trained to approach and consume food in the presence of gradually increasing shock punishment, gradually increasing airblast punishment, or no punishment, and were subsequently tested with full-strength shock of airblast punishment. The results showed that rats could learn 10 resist intense shock or airblast punishmont if they were introduced gradually. While Ss learning to resist shock showed an increased resistance to airblast there was no evidence of the corresponding generalization from airblast to shock.

Miller (1960) has shown that rats could be trained to resist the effects of intense electric shock if the punishment was introduced gradually with in the context of a rewarded response. Terris \& Wechkin (1967) found that rats learning to resist the effects of mild punishment showed increased resistance to more intense punishments. This learned resistance to punishment was not limited to the uriginal aversive stimulus but incluted novel punishments as well.

The purpose of the present sludy was to replicate the study by Terris and Wechkin in a situation where electric shock and airblast punishment are gradually introduced within the context of a rewarded response. It was hypothesized that $\mathrm{Ss}$ learming to resist the effects of gradual shock, or gradual airblast punishment, would show increased resistance to both shock and airblast punishment. METHOD

The $\mathrm{Ss}$ were 48 naive male Holtzman albino rats, weighing $340-370 \mathrm{~g}$ at the beginning of the experiment. They were housed in group cages and had free access to water throughout the experiment. Five days prior to runway training, the $S$ s were put on a $221 / 2-h$ food deprivation schedule which was maintained throughout the experiment.

The main apparatus was a straight-alley runway $36 \times 4 \frac{1}{2} \times 5$ in., constructed of frosted Plexiglas walls with a hinged, clear Plexiglas top. The entire floor consisted of 1/8-in. stainless-steel rods with the centers placed $3 / 8$ in. apart. Placing an animal into the start end of the runway interrupted a photocell beam and activated a standard electric timer which could be terminated manually. The shock source has been described elsewhere (Terris \& Enzie. 1967) and airblast was delivered from an air gun having a source pressure adjustable from $0-30$ psi and an opening of $1 / 8$ in. in diam. The airblast was administered from behind the food cup and approximately 2 in. from the nuse of the $S$.

The experiment was divided into three phases: (1) approach training, (2) resistance trailing. and (3) punishment testing. Approach training in the runway took place on Days 1-6 of the experiment. On Day 1 each $S$ was given me trial which consisted of placing the $S$ into the runway and allowing a maximum of $5 \mathrm{~min}$ to approach the food and hegin eating from a

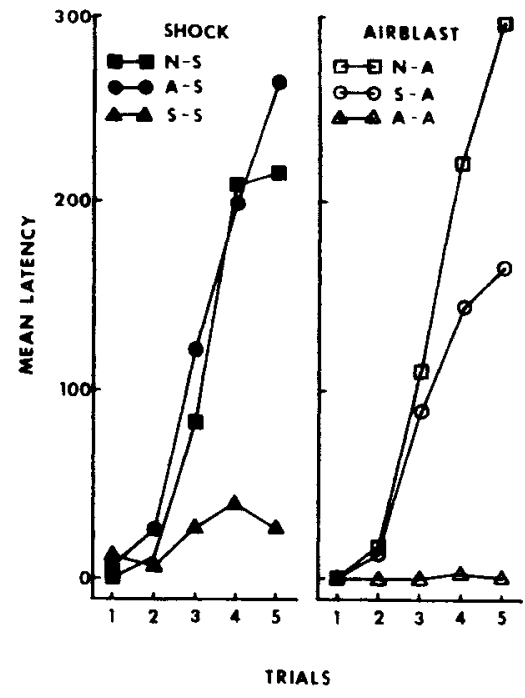

Fig. 1. Mean approach latencies during the five trials of testing as a function of training (shock, airblast, or no punishment) and testing (shock or airblast punishment) conditions.

dish of Purina wet mash located in the goal end of the runway. The $S$ was removed from the runway $45 \mathrm{sec}$ after the beginning of the consummatory response or after $5 \mathrm{~min}$ if the consummatory response was not made. On Days 2-6 of approach training each $S$ was given five massed trials similar to Trial 1 except that the animals were allowed $30 \mathrm{sec}$ of consummatory time.

The resistance training phase took place on Days 7.16 of the experiment with Ss randomly assigned to one of three training groups: gradual shock (S), gradual airblast (A), or no punishment $(\mathrm{N})$. All Ss were given two spaced trials per day with either a $1-\mathrm{sec}$ electric shock, a $1-\mathrm{sec}$ airblast, or no punishment administered when the $S$ touched the food. For the Ss in the gradual shock group the shock was introduced at $.10 \mathrm{~mA}$ and was increased by $.03 \mathrm{~mA}$ each trial until the maximum level of $.40 \mathrm{~mA}$ was reached. Only one punishment was given on each trial and Ss were allowed a maximum of $5 \mathrm{~min}$ to return to the food and eat for $30 \mathrm{sec}$. The procedure for the gradual airblast group was similar except that the airblast was started at approximately 3 psi and was increased by approximately 3 psi until the maximum level of $30 \mathrm{psi}$ was reached. The no punishment group received no punishment during resistance training.

The punishment testing phase of the experiment took place on Days 17-21 of the experiment with the $S s$ in the three resistance training groups randomly assigned to one of two testing conditions: (1) shock testing ( $S$ ) and (2) airblast testing 
Table

Mean Number of Approach Responses Made during Punishment Testing

\begin{tabular}{|c|c|c|c|}
\hline \multicolumn{4}{|c|}{ Training Condition } \\
\hline $\begin{array}{l}\text { Test } \\
\text { Punishment }\end{array}$ & $\begin{array}{l}\text { Gradual } \\
\text { Shock }\end{array}$ & $\begin{array}{l}\text { Gradual } \\
\text { Airblast }\end{array}$ & $\begin{array}{l}\text { No } \\
\text { Punishment }\end{array}$ \\
\hline Shock & 4.88 & 3.62 & 3.57 \\
\hline Airblast & 4.25 & 5.00 & 3.38 \\
\hline
\end{tabular}

(A). During punishment testing each $\mathrm{S}$ was given one trial each day with the animals tested with shock receiving a $1-\mathrm{sec} .40-\mathrm{mA}$ electric shock and the animal tested with airblast receiving a $1-\mathrm{sec} 30$-psi airblast. Again as in resistance training, the Ss were given only one punishment per trial and were allowed a maximum of $5 \mathrm{~min}$ to return to the food and eat for $30 \mathrm{sec}$.

The basic design of the experiment was a 3 by 2 by 3 factorial with the Ss trained to approach and consume food in the presence of either gradually increasing shock, gradually increasing airblast, or no punishment, and were subsequently tested with either full strength shock or airblast punishment. The last dimension was an order factor with the Ss run in one of three time periods throughout the experiment. There were two to three Ss in each of the 18 cells, counterbalanced in such a way that there were eight Ss in each of the six main treatment conditions.

The time taken to approach the food and begin eating was referred to as the approach latency. In all there were six main treatment combinations of the three resistance-training and two punishmenttesting conditions (i.e., Groups $S-S, A-S$, N-S, SA, A-A, \& NA, respectively) with eight $\mathrm{Ss}$ in each of the six groups.

RESULTS AND DISCUSSION

The mean time taken to approach the food and begin eating during the live 1rials of punishment lesting for the main treatment groups is shown in Fig. 1. The nean number of times that animals in the main treatment groups approached the food and began eating during punishment testing is shown in Table 1. An unweighted means analysis of variance (Winer, 1962) of the number of approach responses made during punishment testing as a function of Training ( $S, A$, or $N$ ), Testing ( $S$ or $A)$, and Order $(1,2$, or 3$)$, yielded reliable $F$-ratios for Training, and Training by Testing ( $F$ ratios $=27.4$ and 21.3 , respectively, $\mathrm{df}=2 / 23$ and $\mathrm{p}<.01$ for each ratio), while the $F$ ratio for Testing was not statistically reliable $\quad(F$ testing $=2.56, \quad \mathrm{df}=1 / 23$, $\mathrm{p}>.05$ ).

Testing for simple effects for those Ss tested with shock it was found that while the S-S group was significantly different from both the A.S group $(t=3.99, d f=23$, $p<.01)$ and the NS group $(t=4.15$, $\mathrm{df}=23, \mathrm{p}<.01$ ) the latter two groups did not differ significantly from one another $(t=.16, d f=23, p>.05)$. A similar test for simple effects for those Ss tested with airblast showed that the SA group was reliably different from the NA group $(\mathrm{t}=2.75, \mathrm{df}=23, \mathrm{p}<.05)$.

These results show that animals can be trained to resist both shock and airblast when it is introduced gradually within the context of reward. The results are partially consistent with those of Terris \& Wechkin (1967) in that animals learning to resist shock showed increased resistance to airblast but there was no evidence of generalization from gradual airblast to shock. The failure to find generalization from airblast to shock in this experiment may have been due to the gradual manner in which the airblast was introduced during resistance training. A large part if not all of the aversve propertics of aithlat appeat to depend on a startle or surprise factor. and when airblast in introduced ndually it loses its aversive qualitics. linder liese conditions anticipatory fear would not be aroused and could not become a stimulus for approaching and consuming the food. Thus, little generalized resistance would be expected from gradual airblast to shock (e.g., Terris \& Wechkin, 1967). The method of introducing shock-punishment (i.e., gradual or sudden) would appear to be less important since its aversive qualities are less dependent upon surprise and startle.

The present results are consistent with those of Miller in indicating that gradually increasing punishment is more readily resisted than suddenly introduced punishment. The results do suggest that, at least in the case of airblast, generalization from one punishment to another is greatest when the "training" punishment is introduced suddenly.

\section{REFERENCES}

MILLER, N. E. Learning resistance to pain and fear: Effects of overlearning, exposure, and rewarded exposure in context. Joumal of Experimental Psychology, 1960, 60, 137-145.

TERRIS, W., \& ENZIE, R. Approach-avoid ance conflict behavior as a function of prior electric shock stimulation. Psychonomic Science, 1967, 9, 311-312.

TERRIS, W., \& WECHKIN, S. Leaming to resist the effects of punishment. Psychonomic Science, 1967, 7, 169-170.

WINER, B. Statistical principles in experimental design. New York: McGraw-Hill, 1962.

\section{NOTES}

1. Preliminary results were read at the Southwestern Psychological Association Convention in Houston, April, 1967.

2. The experiment was part of a Masters thesis completed at the University of OkJahoma, 1966. 